\title{
Author Correction: Pharmacological inhibition of PRMT7 links arginine monomethylation to the cellular stress response
}

\author{
Magdalena M. Szewczyk, Yoshinori Ishikawa, Shawna Organ, Nozomu Sakai, Fengling Li, Levon Halabelian (D), \\ Suzanne Ackloo (1), Amber L. Couzens, Mohammad Eram, David Dilworth (1), Hideto Fukushi, Rachel Harding, \\ Carlo C. dela Seña, Tsukasa Sugo, Kozo Hayashi, David McLeod (D), Carlos Zepeda, Ahmed Aman, \\ Maria Sánchez-Osuna (D), Eric Bonneil (D), Shinji Takagi, Rima Al-Awar, Mike Tyers (D), Stephane Richard,

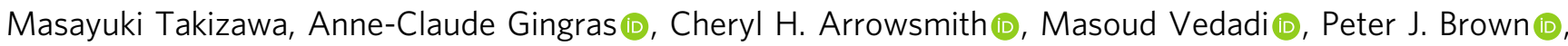 \\ Hiroshi Nara \& Dalia Barsyte-Lovejoy (1)
}

Correction to: Nature Communications https://doi.org/10.1038/s41467-020-16271-z, published online 14 May 2020.

The original version of this Article omitted the following from the Acknowledgements:

Research supported by SU2C Canada Cancer Stem Cell Dream Team Research Funding (SU2C-AACR-DT-19-15) provided by the Government of Canada through Genome Canada and the Canadian Institute of Health Research, with supplemental support from the Ontario Institute for Cancer Research, through funding provided by the Government of Ontario. Stand Up To Cancer Canada is a Canadian Registered Charity (Reg. \# 805506730 RR0001). Research Funding is administered by the American Association for Cancer Research International-Canada, the Scientific Partner of SU2C Canada.

This has now been corrected in both the PDF and HTML versions of the Article.

Published online: 26 May 2020

\footnotetext{
(c) Open Access This article is licensed under a Creative Commons Attribution 4.0 International License, which permits use, sharing, adaptation, distribution and reproduction in any medium or format, as long as you give appropriate credit to the original author(s) and the source, provide a link to the Creative Commons license, and indicate if changes were made. The images or other third party material in this article are included in the article's Creative Commons license, unless indicated otherwise in a credit line to the material. If material is not included in the article's Creative Commons license and your intended use is not permitted by statutory regulation or exceeds the permitted use, you will need to obtain permission directly from the copyright holder. To view a copy of this license, visit http://creativecommons.org/licenses/by/4.0/.
}

(C) The Author(s) 2020 